\title{
Joyce Cary's Technique Of Story-Telling: A Study On The Angle of Vision And Character-Building
}

\author{
Dr. Imam Alam Khan \\ JCC/ King Abdulaziz University \\ Jeddah, Kingdom Of Saudi Arabia
}

\begin{abstract}
Joyce Cary (1888-1957) is an original novelist. He is a challenging writer of famous novels who is, no doubt, inimitable and amazingly unique. He is a moralist, a traditionalist, and a conservative who can never think of the irrational dominating the rational. Like other great artists, Cary also has a theme or an idea of life profoundly felt and founded in some personal and compelling experiences. A study of Cary's novels presents a vibrant and comprehensive idea of the world, which constitutes his visions and forms his original characterization. And, this is the basis of all sixteen novels he has written, and tried to build his strong characters through his angle of vision. Legouis and Cazamian write in 'History of English Literature', "He made use of everything; his Irish birth, African contacts and the intuitive vision of modern times." (Legouis \& Cazamian, $P$-1385) He regards freedom as the fundamental reality of life, much in the same way as Conrad believes that the world rests principally on the idea of fidelity; or as Henry James regards man's desire to live as the great truth about life. His footing is as Hardy holds the injustices of life the cruelty of blind fate, destroying innocent and guilty alike to be the fundamental truth about life, or as Somerset Maugham thinks that man is in constant search for freedom from bondage of all kinds. Joyce Cary is an adept craftsman who takes great pains in choosing the angle of vision from which he is to narrate his story. His novels reveal how he has experimented with various narrative techniques in order to make his meaning unmistakably flawless to the reader. Cary's first three novels, 'Aissa Saved', 'An American Visitor', and 'The African Witch', exhibit his skill in employing the most common technique of story-telling, the omniscient author's viewpoint, which is also known as direct narrative, or epic manner of storytelling. "His stories absorb our interests, and take us to a new world, away from our routine work where we feel, experience and enjoy". (Khan, Imam Alam: P-60) So, this research paper is going to investigate whether Joyce Cary, the author of sixteen novels, has the author's assumed omniscience method or not, and which particularly suits Cary or not? Does it enable him to express his vision of life easily and effectively? Are his other techniques of story-telling are unique, quite more impressive as well as more effective as the direct narrative methods? This paper is going to discuss the questions in detail to substantiate the unique techniques used by Cary.
\end{abstract}

Key Words: technique, angle of vision, originality, characterization, theme, life, fiction

\section{INTRODUCTION}

"Novel is the interpretation of human life by means of fictitious narrative in prose" (Baker, E A: P-V) says E.A. Baker. Story in the opinion of E.M. Forster is the life-blood of novel. Those who are traditionalist emphasize his aspect quite a lot but those who are modernist do not lay much emphasis on this aspect of novel. So, it is an indisputable fact that a story-teller can be a novelist but the novelist is not necessarily a story-teller. Among the seniors of Joyce Cary was S. Maugham who laid great emphasis on the story element and considered it to be the core of the art of fiction. To him, the novel is a story first and foremost. As a writer of fiction, he says, 'I go back, through an innumerable generation, to the teller of tales'. In the same vein, he declares, 'I have never pretended to be anything but a story-teller. It has amused me to tell stories and I 
have told a great many'. Cary, too, emphasizes the significance of the story in a work of fiction by holding that a good novel ought to have a story, which should be coherent and persuasive. He fully agrees with Maugham and reacts sharply against the modern serious novelists who have often little or no story to tell. He does not draw a line of demarcation between the story and the plot and so he greatly differs from E.M. Forster on this point. He fully agrees with the view of S. Maugham who states that "a plot is merely the pattern on which the story is arranged."(Maugham, S: P-217) Cary tried to carry over the realistic trend. And, that is very important. His first trilogy, "Herself Surprised, 1941; To Be a Pilgrim, 1942; and The Horses' Mouth", 1944, deal with the affluences and the relationships among the characters. In the same way, in the second trilogy, Cary tried to interweave the events and individuals destinies. Gulley Jimson's character is a character of a relentlessly dedicated artist. The objective of Cary here was to deal with English history through English eyes. Forster opines, "Human beings have their great chance in the novel. They say to the novelist: create us if you like, but we must come in."(Forster, E M: P-149)

A lot of experiments were going on the realm of fictional technique while Joyce Cary was writing his novels. He was well aware of those technical innovations. Under those impacts, the technique of novel-writing underwent changes of wider ramifications. Traditional English novels, from Henry Fielding to H.G. Wells, had well-defined stories or plots. However, in the hands of D.H. Lawrence, James Joyce, Virginia Woolf and Dorothy Richardson, the story-novel went out of fashion. Characters were no longer viewed from outside as men and women, living, talking and acting in a three-dimensional world, but were examined in minute details from inside. Not what they said and did, but what they felt and thought. Inner feelings were treated as the realities of human character. At such time, Joyce Cary was just learning to be a novelist. It was unique of him that he could afford time for keeping himself abreast of these experiments. Though a traditionalist and a great champion of story-element, he was struck with James Joyce's 'A Portrait of Artist as a Young Man'. He was full of praise for the sincere portrayal of the artist in James Joyce's novel and so he, vehemently, disagreed with H.G. Well's view who did not find any novelty in Joyce's novel. At one stage of his career, he has taken a fancy to Conrad's technique as well whom he considered to his master. Conrad's 'The Arrow of Gold' exercised magical impact on his mind yet Cary never became an imitator of his technique or any other's technique current in fashion. Cary tried to write original novels in his own style in the main stream of the traditional English novels in which story-telling and characterbuilding are outstandingly important. As Kenneth Richardson points out:

“............his (Cary's) books display a gift for story-telling and an ability to create a great diversity of characters; and he writes with a combination of dedicated craftsman-ship, imaginative invention and seriousness of intent."(Richardson, K.R.: P-112)

\section{DISCUSSIONS}

Cary was an adept craftsman who took great pains in choosing the angle of vision to narrate his story. All sixteen novels of Cary reveal how he experimented with different narrative techniques in order to make his meaning unmistakably clear to the readers. Cary's first three novels: 'Aissa saved', 'An American Visitor' and 'The African Witch' uniquely exhibit his skill in employing the most common technique of story-telling, the omniscient author's view point, which is also known as direct or narrative, or epic manner of story-telling. Since this method has the advantage of flexibility in terms of omniscience, which suited Cary at the beginning of the career. It enabled him to express his angle of vision of life very easily and effectively. Hudson praises Cary's selection and treatment of the subjects as well as of the characters. He has his say in the following words; "outstanding among recent novelists, Joyce Cary, was also the most varied in his selection and treatment of his subjects." (Hudson, W H: P-305) 
In 'Mister Johnson', Cary makes a new experiment with third-person point of view by writing the novel in the present tense. He used the present tense because Johnson lives in the present. In the preface to the 'Carfax Edition' of 'Mister Johnson', Cary gives the reason of writing the novel in the third-person present tense. He says, .... . But in a novel written in the present tense, the reader, too, is in the present and he drifts down the stream of events in a mood which is not "contemplative but agitated". (Cary, Joyce: P-9) The narrative in the third-person present tense is quite appropriate for Mr. Johnson. The device gives the readers the impression that he is watching an action in progress, whereas the past tense makes him conscious of an action already completed. Since improvisation is the hallmark of Johnson's Character, Cary's use of the present tense to communicate the sense of a character constantly reacting to his world is remarkable. The technique also makes Johnson's quick emotional reaction and decisions convincing. The novel illustrates the writer's effective use of the narrative device, too.

In, 'Charley is My Darling', Cary employs the "Omniscient" third-person point of view in combination with the past and the present tenses. He uses the past tense for describing a thing, a scene, and the present tense for narrating the story. His use of both the tenses enables him not only to comment on character's motives, but also to create on the reader's mind the impression that the action is on progress, and that the characters are continually reaching their world. Charley's quick emotional responses and his development to maturity are very much convincing. Walter Allen eulogizes Cary's use of the historic present tense which enables him to employ his generalizations for making his characters more convincing. What is remarkable about these generalizations is that, unlike the generalizations in the novels of Thackeray and George Eliot, they are never "Shocking intrusions" on the action. (Allen, Walter: P-16)

'The Moonlight' and 'A Fearful Joy' are written in the classical omniscient manner. In 'Charley is My Darling' and in 'The Moonlight', Cary intends to accomplish the difficult task of presenting the nature of sex of two or three generations of women. Consequently, he needs, as he says, not only a big canvas and a contemplative mood, but also "the classical third person not centered in one mind but entering into all the characters". (Cary, Joyce: P-11) In order to make the thirdperson narrative method effective, convincing and interesting; Cary makes it as much dramatic as possible by avoiding direct comments and making characters reveal the events through dialogues. Therefore, it is not surprising that in a book of three hundred and fifteen pages; it is only on one page (page two hundred and eighty nine) that inverted commas are not employed. This narrative device, according to Paulina June Salz, greatly helps the novelist in arranging the material of the book in an orderly shape. In, 'A Fearful Joy', Cary treats social, political and intellectual changes occurring in England from eighteen eighties to nineteen forties so as to show that man's creative freedom of the imagination is at the root of all the changes in the world. In order to present this vast material in an effective and compact form, he mainly concentrates on the central figure of the book, Tabitha Baskett. He records at length her responses to life through which the reader is kept constantly informed of the different changes taking place in England.

It is obvious that Cary holds the view that man's creative freedom of mind gives him a vision of life, which is so important for him that he strains every nerve to attain it. So people in Cary's novels are replete with vigour because they madly strive throughout their lives to materialize their visions and beliefs. If they fail to achieve their objectives, they feel isolated and because of frustrations. As Cary was a modernist, a product of twentieth century, so the idea of isolation also is a recurrent theme of his novels. In his novels, he repeatedly presents the idea that man is isolated because he is a free creative being. Since man creates his unique universe in consonance with his idea and beliefs so in one way he lives in a kind of unavoidable isolation. Cary's central characters in particular and other character in general feel the tormenting 
weight of the sense of loneliness. Cary believes that man makes any sacrifice in order to achieve his view of life. Freedom may take a man closure to isolation but it is this unique experience that goes a long way in making him a glorious creative being that is ready to sacrifice even the basic needs of his body for the sake of some ideal. In his opinion, men and women are not unique in an economic structure; they are living-souls who are ready to ignore even the primary needs of their bodies for some ideal satisfaction, glory of learning religion or beauty. (Cary, Joyce: P-150)

"There will always be plenty of luck and bad luck in human affairs, there will always be suffering and disaster. If you have freedom, you have got to love evil in the world you cannot get away from it". (Wright, Andrew: P-109) Therefore, facts make it crystal clear that in Cary's novels there exist conflicting ideas what we can call 'good' and 'bad', moral and immoral, evil and virtuous. Cary was of the view that a novelist cannot and should not ignore the facts of life and their impacts on the individuals concerned, for in his opinion a novel is not only a source of entertainment but also a source of moral uplift. He clearly says that a novelist has to keep his eyes well-fixed on the questions of morality and immorality and of what is right and what is wrong in this world of flux, in his opinion, "All writer have and must have, to compose any kind of story, some picture of the world, and of what is right and wrong in that world. And the great writers are obsessed with their theme. They are sure they are right and that their message would save the world". (Cary, Joyce: P-109)

Cary's success in accomplishing all this, to a great extent, can be attributed to his skillful handling of the device of the third-person present tense. Robert Bloom says in this connection: 'Using a third-person mode largely limited to Tabitha's consciousness, and casting the whole narrative in the present tense, with its aura of immediacy, even urgency, Cary sees to it that the novel has a centre in his heroine as well as in the relentless historical changes'. The novel begins with the third-person past tense. But after the third paragraph of the third chapter, the novelist shifts to the third-person present tense, which becomes the uniform narrative method in the rest of the book. The scene, presenting the shift from the past to the present, is remarkable. The novel begins in the past tense because the author describes Tabitha's past life before her intimacy and elopement with Bonser, which proves a turning-point in her life. After this incident, Tabitha lives perpetually in the midst of changes, which Cary tries to catch in their actual moments. Hence from this moment onward, he employs the device of the thirdperson present tense. Thus, his shifting from the past tense to the present tense arises from the necessity. 'A House of Children' marks a change in Cary's technique of story-telling. He employs the first-person method in this novel. Evelyn Corner, the narrator of the story, looks back over a summer spent in Ireland when he was eight years old. The first person point of view of this novel is strikingly different from that of the two trilogies in as much as it is not accompanied by a lot of action. In this novel, the narrator indulges in frequent common generalizations, and makes a use of both, the past and the present tenses. On the very first page of the novel, there is a generalization regarding the essential nature of small children, and consequently a shift from the past to the present: "I was waiting for a sail, probably my first sail into the Atlantic. Somebody or something must have fixed that moment upon my dreaming senses, so that I still possess it. Small children are though happy, but for most of the time they drift through sensations as a pantomime fairy passes through colored veils and changing lights". (Cary, Joyce: P-14)

The passage from the novel, quoted above, serves to illustrate Cary's ability to make a two-fold achievement by the use of this narrative technique: to record the actual sensations of childhood, and also to portray childhood itself. The device makes the novelist's autobiography of childhood a universal portrait of childhood itself. The use of the present tense enables the 
writer to realize his aim of arresting, in the narrative, the very moments of action, and thus giving a realistic account of life.

The two trilogies show that Cary's use of the first-person narrative mode enables him to illustrate his concept of man creating his own unique world. By abandoning the "omniscient" manner and thus withdrawing himself completely from the world of his novels, he allows the six narrators of the two trilogies complete freedom of presenting the worlds they have shaped for themselves. In the preface to the First Trilogy, he writes that the narrative technique in the first person is closely related to the philosophical doctrine of the creative freedom of the mind expressed in the three novels of the trilogy. He intends to show three people, every one living in his own world by his own ideas and narrating his own life and struggles. That is why, every one of his three chief characters, as he says, has to write in the first person and reveal his own world in his own style. Thus, the first-person mode of narration is indispensable to the two trilogies, because it is the only adequate method for communicating the multiplicity of viewpoints. In fact, Cary exhibits in the two trilogies that skill in the use of the first-person point of view, which we discover in Hemingway's, 'A Farewell to Arms' and 'The Sun Also Rises'. It is very much discovered in Maugham's 'Cake and Ale' and 'The Razor's Edge'.

The first-person point of view as employed in 'Except the Lord' differs from that used in 'Prisoner of Grace' in two ways. Firstly, in this novel, there is comparatively a greater use of comments and generalizations in the first person present tense. Secondly, Cary resorts to the device of shifting from the past tense to the present, as Chester narrates some of the episodes related to his past. Most of the first chapter is in the present tense. Though the narrator, old Chester Nimmo, describes the incidents of his early childhood, yet he uses the present tense because the recollection of those past incidents is very much immediate to him and forms an integral part, even, of his present life. After the first sentence of the second paragraph of the book, he begins to describe his life. He writes in the past tense something about his childhood and his father, and thereafter, describes in the present tense, a few old incidents vividly implanted in his mind:

"I remember my mother coming to us one evening and supper with a small tin in her hands, she opens it before my father and turns it upside-down. But I see that she is smiling and I am puzzled by the idea that anyone can, laugh at my father",

"I recall with great vividness another scene. My father is going to market Suddenly a huge red man appears from the hill - he speaks to my father, argues, begins to wave his great fists".

"I know the man and fear him a drunkard whose wife also drinks"

"My father, a small figure, thin, already gray-haired, answers sharply, 'If I gave you money, you had only drunk it. And what are you doing here'? Suddenly the giant falls on his knees and begins to weep". (Cary, Joyce: Pp 5-6)

Cary also employs the flash-back technique quite skillfully. The "flash back", though a theatrical and cinematographic device, is also now employed in the modern novel, too. It enables the writer to delineate incidents occurring prior to the opening scene of book. The use of this technique upsets the chronological order of events. The story does not move uniformly forward in time, but travels back in the past at one or more stages and reappears in the present. Recollections, narration, dream-sequences and reveries are the various devices used by a writer to depict past incidents. Cary uses the flashback technique in two of his novels, 'To Be a Pilgrim' and 'The Moonlight'. Its principal form is the main characters' recollection, though at times, the past reappears in a character's narration or reverie also. Wilcher in 'To Be a Pilgrim' and Ella in 'The Moonlight' repeatedly remember their past events. The flash-back; in 'To Be a Pilgrim' and 'The Moonlight' is the only technical device whereby Cary convincingly 
conveys his meaning artistically and effectively. Wilcher in 'To Be a Pilgrim' and Ella in 'The Moonlight' must be presented though the flashback because "their life is the life they have lived rather than the life they are living". (Hardy, Miss Barbara: P-183)

The two novels depict a fight between the past and the present. Past and present are shown intersecting and interrupting each other throughout the two narratives. While discussing his use of the flash-back technique with the Paris Review Interviewers, Cary remarked:

"The flash-back in my novels is not just a trick. In, for example, 'The Moonlight' I used it in order to make my theme possible. It was essential to compare two generations. You can't do that without a flashback contrast; the chronological run-through by itself is no good". (Cary, Joyce: P-50)

Besides revealing Wilcher's character artistically, the flash-back serves another purpose. It enables the novelist to make the past criticize the present directly as well as obliquely. Sometimes Wilcher, one of the last relics of the old generation, comes in direct conflict with Ann and Robert who represent the present generation. But quite often his recollection of the past and his comments on it offer a brilliant indirect criticism of the new world, inhabited by Ann, Robert and others. Wilcher criticizes the younger generation, lacking faith and religion. He thinks that it is futile to talk to children like Ann and Robert because they have only information, and not education. They do not mind going to bed which other, but are shocked to hear that a bad child is punished. He Affirms that hard upbringing, had greater happiness in their childhood than Robert and Ann had. The novel constantly portrays the conflict between the present and the past, the new and the old. The present generation, characterized by aimlessness, despair, lack of faith, coldness, lack of vitality and warmth, is criticized by the old generation which, as revealed through the flashback, had purpose, faith, religion, hope, warmth and energy.

In short, the use of the flash-back in 'To Be a Pilgrim' enables Cary to present his theme of the 'creative freedom of the imagination' effectively. The novel demonstrates that men create their own worlds and are, therefore, perpetually in conflict with one another. Thus, Wilcher creates a peculiar world of his own. Lucy and others of her generation lived in a world different from that of their father's. Lucy, Edward, Wilcher, Sara, Julie, Bill and Amy existed in their own worlds and hence, clashed with one another. The World of Lottie and others was different from those of their predecessors, and was incomprehensible to Wilcher. Cary's use of this device contributes a good deal to the condensed form in which the vast material of the book is cast. If he had narrated events chronologically, the whole presentation would have lost much of its effectiveness and vividness.

The use of the flashback here is necessary, since Bessie's concept of sex, love and marriage is to be brought to light in order to present the different views on sex of the three women of the same generation- Rose, Bessie and Ella. It is made clear to us that Bessie was a first with a craving for physical pleasures. Thus Bessie, as portrayed through the flashback, presents a contrast to Rose in regard to sex, love and marriage. Ella's sympathy and support for Bessie show that she and Rose have different views on love and marriage. In the last chapter of the novel, the fight between the past and the present reaches its climax. The past, as shown through the recollections of Ella, offers a direct criticism of the present. Just at the beginning of the chapter, Ella is shocked by the corrupt careless and defiant looks of Amanda, who has committed guilt but has not the moral sense and power to accept it. Her mind goes back to old days, and she sees in Bessie and Rose an antithesis of Amanda. 
In short, the flash-back is necessary for the novel, 'The Moon-Light'. It enables the novelist to achieve his aim of dramatic presentation of different views on sex, held by the women of two or three generations by depicting the working of woman's creative imagination in the sphere of sex-life. With the help of this device, Cary succeeds in placing, side by side, the women of old and new generation, and in presenting simultaneously their conflicting attitudes towards sex. In the earlier part of the novel, he portrays various ideas of the old generation in a way, which suggests an implicit criticism of the view on sex, held by the new generation. But as the story progresses, the indirect conflict, between the women of old and new generations, becomes frequently direct. Thus in the earlier part of the novel, Rose, Bessie and Ella - the representatives of the old generation - are shown in conflict with one another, and their views on sex, expressed through these conflict criticize implicitly the concept of sex, held by the new generation of Amanda, Kathy and others. After-wards the conflict between Iris and Rose - the two women belonging to two older generations is depicted. And in the second half of the novel, the conflict between Rose, Bessie and Ella on one hand and Amanda and Kathy, on the other, becomes more and more apparent. Rose, Bessie and Ella embody vigour, passion and imagination, whereas, Amanda and Kathy are dull, cold and excessively intellectual. Similarly, the men of old generation like Mr. Venn, Groom, Geoffrey Tew and Ernest Cranage, whose lives are portrayed though the flashback, presents a sharp contrast of the new generation represented by Robin and Harry, who regard love and marriage as only a matter of convenience and adjustment.

Another feature of story-telling technique, quite conspicuous in the novels of Joyce Cary, is the technique of 'internal monologue'. "The technique of the 'interior monologue', according to Dorothy Van Ghent, is a modification of the subjective point of view. It is not a departure from traditional convention, for even Fielding used this point of view when he wanted to show 'from the inside' how a character's mind worked; but it is an employment of the subjective point of view throughout the novel, instead of sporadically, as in the older English novel - and it follows more devious and various paths of consciousness than traditional novelists were concerned with". (Ghent, Dorothy Van: P-267) Though the term 'internal monologue' is very close to 'stream of consciousness, and was used at just interchangeably with it. It is erroneous to regard the two expressions as identical in meaning. The 'internal monologue' does not convey the idea of flux, the disordered and fluid state of mind, which the term 'stream of consciousness' suggests. It denotes the device by which thought associations are rendered is a considerably logical progression. The object of this technique is to enable the reader to enter the inner life of a character straightway, and to know his thoughts, as they arise in his mind. However, this technique has the appearance of being associational, illogical and free of authorial control. The closing part of Joyce's 'Ulysses', dealing with Molly Bloom, happens to be the finest specimen of the direct interior monologue, while the novels of Dorothy Richardson and Virginia Woolf employ the indirect internal monologue.

In the first person narratives, especially in the two trilogies, Cary endeavours to efface himself and take the reader directly to the mental experience of the principal characters. Prof. Andrew wright thinks that in the novels included in Cary's two trilogies, there are six kinds of interior monologue. (Wright, Andrew: 1958) But it is only in 'The Horse's Mouth' that one is directly inside the mind of Jimson, with his ever increasing passion for painting and his acute sense of the world's injustice. In this novel, Cary has presented the stream of consciousness of Gulley Jimson through the device of the interior monologue.

Cary's employment of internal monologue in his novels is so skillful and dexterous that it adds to the development of them as well as the characters. For example, in 'The Horse's Mouth', Cary paints the creative imagination of an old painter, Gulley Jimson, who is obsessed with picture 
and picturesqueness. However, he does not show him painting a large number of good pictures. All the four pictures - the fall, the New Fall, the Raising of Lazarus and the Creation that Jimson is shown drawing remain incomplete, and are not much appreciated by anyone except Nosy and himself. This is due to the fact that Cary is mainly concerned with Jimson's inner-life. Since the paints in this novel the inner-life of man, he adopts the technique of the interior monologue.

A characteristic feature of the device of the internal monologue as employed in 'The Horse's Mouth' is the intersection of action and perception. Cary like Graham Greene, Evelyn Waugh and Maugham avoids those factors which impede the tempo of the narratives. So, his novels do not have lengthy dialogues and descriptions. Even in 'The Horse's Mouth' wherein he employs the device of internal monologue, he does not indulge in long analyses of the thoughts, crowding Jimson's mind. Hudson goes on describing the genius of the protagonist of novel in the following words; “... to the shameless doings of a rascally artist (The Horse's Mouth). Even if the last-named novel is not Cary's best, it is unique in so far as it succeeds in carrying conviction that the hero, the scurrilous down-at-heel Jimson, really is a man of genius". (Hudson, W H:P-305) No doubt, there are numerous reflections on morality, spiritualism, politics, art and life in general; but none of them is as lengthy as to obstruct the progress of events for a considerable length of time. The only exception, perhaps, is the long philosophical discussion between Marie Hasluck, Cottee and Bewsher on the civilization of the Birri of Africa in 'An American Visitor'. But this too, is related, though loosely, to the mainstream of the narrative.

The quick tempo is especially noticeable in those novels of Cary where in events stretch over a long period of time. In 'A Fearful Joy', for instance, the time duration is about sixty years. During this long period, Bonser and Tabitha pass from youth to old age and the former dies; their granddaughter attains to youth, becomes mother and goes abroad. Two generation pass out of existence, and are succeeded by the third. In 'Castle Corner', 'Herself Surprised', 'Prisoner of Grace' and 'Except the Lord', too, the actual time duration is much longer than our sense of the passage of time derived from the story. The events spreading over decades in these novels are developed rapidly and a close-knit account of them is given to us. Consequently, the impression of the passage of time that anyone of these novels gives is much shorter than the actual time duration. Tempo is quick even in those novels wherein past events of several years are recalled. In 'The Moonlight' and 'To Be a Pilgrim', for example, the stories of the principal aged characters are presented through several closely-knit pictures. The result is that the tempo of these narratives is accelerated, and the events of more than five decades pass rapidly before our eyes. A long series of events are repeatedly recalled in the retrospect. In Cary's other novels like 'A House of Children' and 'The Horse's Mouth', too, wherein past events are recalled, the narrative proceeds from one significant event to another without mentioning the intervening details naturally, tempo is accelerated, and a long series of events pass quickly before our eyes.

Cary, no doubt, took advantage of some of the modern discoveries in fictional technique. Like Conrad, he had unremitting care for form. James Joyce's influence is perceptible in his 'A House of Children' and also in his trilogies, which are replete with stream of consciousness's passages and artistic epiphanies. A review of 'The Horse's Mouth', which is actually a portrait of the artist as an old man, convinces us of Joyce's influence. However, Joyce Cary doesn't miss his originality. For what picture of stream of consciousness, James Joyce presents in the third person, Joyce Cary does the same in the first person. Joyce Cary does the same in the first person narrative. One feels quite tempted to agree with William Van 0 Connor's pronouncement that Cary's novels marked a return to: 
...................something like its old form without sacrificing the modernist discoveries. (O'Connor, W V: P-3)

In Ulysses, for example there is little movement of time. James Joyce records the experiences of a few characters during the course of a single day. The progress of events of the novel is very slow-Time almost stands still in the book because the novelist is principally concerned with the consciousness of the character and the coherence of their mind, and in indifferent to all those factor which accelerate tempo, namely drama, suspense, instead of emotion and a logical suspense, instead of emotion and a logical sequence of events. But this is not the case with 'Wuthering Heights' because of the rapidity, dramatic intensity a logical coherence of events. As a result of these, years pass before our eyes with great rapidity.

Whatever be the nature of Cary's vision of life, it is undoubtedly quite a deep one. It opens up new vistas of life to our wondering eyes. He is a thought writer and a philosophical novelist who believes in the efficacy of novel as an art which not only pleases us but also enables us to have a better understanding of the world and human nature. His tales do absorb our interest, taking us out of the routing of our work a day life. He is convinced that life is tragic but it is worth-living. He finds life full of injustice and evil, and avers that since man is free, he is doomed to loneliness and destruction but according to him the pith \& core of living is creation. And it is this urge of creation, which drives men on in the face of tragedy, injustice, destruction and loneliness. Cary no doubt believes in the tragedy of life, but he is not a pessimist because he has full faith in the imperishability of life. He, no doubt, sends a message of hope to the world which becomes crystal clear in these words of his, "..... if all the life on the earth should be over whelmed in an afternoon, the womb of ocean would still hold the teeming seed and in its own time ...bring forth another race of man, other cultures".

Cary like Graham Greene, Evelyn Waugh and Maugham avoids those factors which impede the temp of the narratives. Thus, his novels do not have lengthy dialogues and descriptions. Even in 'The Horse's Mouth' wherein he employs the device of internal monologue, he does not indulge in long analyses of those thoughts, crowding Jimson's mind. No doubt, there are numerous reflections on morality, spiritualism, politics, art and life in general; but none of them is so lengthy as to obstruct the progress of events for a considerable length of time. The only exception, perhaps, is the long philosophical discussion between Marie Hasluck, Cottee and Bewsher on the civilization of the Birri of Africa in 'An American Visitor'. But this too, is related, though loosely, to the mainstream of the narrative.

\section{CONCLUSION}

In fine, it is obvious that the artistry of storytelling by Joyce Cary is unique and original in his way of presentation. He uses his technique to put his angle of thought obviously. He walks with the space of his reader. He is always very close to his reader. He succeeds in his aim of expression of his angle of thought and vision. He influences his reader easily and effectively. It makes us obvious that Cary was an adept craftsman who takes great pains in choosing the angle of vision from which he is to narrate his story. The posed write-ups above prove that Joyce Cary is an original and a challenging writer of famous novels who is, no doubt, like all great artists, inimitable and amazingly unique in his story-telling technique. I would like to support my investigation with the words of Edward Albert, a famous writer of the History of English Literature of OUP, who praises Cary' characterization in the following words, "Himself a vigorous extrovert, he delighted in portraying exuberant, bizarre figures who existed according to a code of their own. He had the rare gift of combining comedy, even farce, with the pathetic and the movingly beautiful. His portrayal of character was objective; he detested 
nothing but what was dull, and he appreciated eccentricity when it arose to imaginative heights". Albert, Edward: P-621)

\section{References}

Albert, Edward: History of English Literature, OUP, India, Fifth Edition. 2018. P-621.

Allen, Walter: Joyce Cary: Longman, Green, London, 1953. P-16

Baker, E.A., Preface to Ashenden, William Heinemann Ltd., London 1948. P-V

Cary, Joyce: Prefatory Essay to Mister Johnson, Carfax Edition, Michael Joseph, London, 1959. P-9

Cary, Joyce: Prefatory Essay to the Moonlight, Carfax Edition, Michael Joseph, London, 1959. P-11

Cary, Joyce: The Case for African Freedom, Secker and Warburg, London, 1944. P-150

Cary, Joyce: Art and Reality, Anchor Edition, New York, 1958. P-109

Cary, Joyce: A Fearful Joy, Carfax Edition, Michael Joseph, London, 1962. P-14

Cary, Joyce: Except the Lord, Michael Joseph, London 1953. Pp- 5-6

Cary, Joyce: Writers at work, the Paris Review Interviews, Cowley Malcolm, Ed. London, 1958, P-50

Forster, E M: Aspects of the Novel, Penguin Books, New Delhi, India, 2005. P-149

Ghent, Dorothy Van: The English Novel Form and Function, Harper Torch books Edition, New York, 1961. P-267

Hardy, Miss Barbara: Form is Joyce Cary's Novel, Essays in Criticism, Vol. IV, 1954. P-183

Hudson, W H: An Outline History of English Literature, AITBS Publisher, India, 2014. P-305

Khan, Imam Alam: IJALEL, Vol. 4, No. 1, 2015.

URL: http://dx.doi.org/10.7575/aiac.ijalel.v.4n.1p.60

Legouis, Emile, Cazamian, Louis \& Vergnas, Raymond Las: Macmillan, India, 2012, P-1385

Maugham, S: The Summing Up, William Heinemann Ltd., London, 1948. P-217

O' Connor, W.V: Joyce Cary, Columbia University Press, New York, 1966. P-3

Richardson, K.R.: The Twentieth Century Writing, the Hamlyn Publishing Group Ltd, 1969. P-112

Salz, Paulina June: The Novels of Joyce Cary in Relation to His Critical Writings, University of California, California. P-177

Wright, Andrew: Joyce Cary: A Preface to His Novels, Chatto and Windus, 1958. P-109 